\title{
ANALISIS PEMBELAJARAN KOOPERATIF MELALUI MODEL THINK PAIR SHARE (TPS) DALAM MENCAPAI HASIL BELAJAR IPA SISWA SEKOLAH DASAR
}

\author{
Uus Toharudin \\ Dosen FKIP Universitas Pasundan Bandung \\ uustoharudin08@yahoo.com
}

\begin{abstract}
Still the low subjects of Science Sciences Elementary School grade IV students became an issue for teaching teachers in schools. IPA Science is an important student eye in improving the way constructive thinking students in responding to the development of the world and the universe. Research objectives to increase student learning activities as per expectations and target goals set by the school. Research methods using quasi experiments are descriptive survey, field study, Instrutemen, and literature study. The results showed significant differences in student creative thinking skills and class teachers after using the Think-Pair-Share (TPS) Cooperative learning model for SCIENCE subjects for elementary school grade IV students.
\end{abstract}

Keywords: TPS, learning outcomes, and SCIENCE courses

\begin{abstract}
Abstrak - Masih rendahnya mata pelajaran sains IPA siswa kelas IV SD menjadi persoalan bagi guru ajar di sekolah. Sains IPA adalah mata pelajar penting dalam meningkatkan cara berpikir konstruktif siswa dalam merespon perkembangan ilmu pengetahuan alam semesta. Tujuan penelitian untuk meningkatkan aktivitas belajar siswa sesuai harapan dan sasaran target yang ditetapkan sekolah. Metode penelitian menggunakan quasi eksperimen bersifat descriptive survey, field study, instrutemen, dan studi literature. Hasil penelitian menunjukan terdapat perbedaan signifikan kemampuan berpikir siswa dan guru kelas setelah menggunakan model pembelajaran kooperatif Think-Pair-Share (TPS) untuk mata pelajaran IPA bagi siswa kelas IV Sekolah Dasar.
\end{abstract}

Kata Kunci : TPS, hasil belajar, dan mata pelajaran IPA

\section{PENDAHULUAN}

Studi kooperatif merupakan model pendidikan bagi anak didik pada lingkup yang kecil dengan penekanan kolaboratif pesertanya secara heterogen, yang terhimpun dalam sebuah struktur kelompok antara empat sampai enam orang (Slavin, 2010). Studi kooperatif tiada lain, belajar bersama melalui kelompok kecil yang saling membantu satu sama lain (Thompson, 1995). Belajar berkelompok belum tentu mencerminkan pembelajaran kooperatif. Sebab itu, agar benar-benar mencerminkan pembelajaran kooperatif, maka diperhatikan elemen pembelajaran kooperatif (Johnson DW, Johnson RT, \& Holubec, EJ : 2004).

Studi lingkungan sekitar sekolah, misalnya, bidang studi Ilmu Pengetahuan Alam (IPA) bagi anak didik Sekolah Dasar (SD), studi kooperatif dalam perspektif IPA yakni bagaimana mengubah cara belajar anak didik dalam memahami masalah dan pemecahan masalah yang terjadi dalam lingkungan sekolah. Sebab itu, pengayaan wawasan keilmuan anak didik harus holistik. Pembelajaran tersebut, dikenal dengan 
Think Pair Share (TPS). Model TPS atau berpikir berpasangan adalah jenis pembelajaran kooperatif yang dirancang untuk mempengaruhi pola interaksi anak didik. Model ini dikembangkan pertama kali oleh Lyma dan Koleganya di Universitas Maryland (Kurniasih, 2015:58).

Proses thinking (berpikir) setiap anak didik diajak berpikir responsif, mandiri, dan mencari jawaban dan solusi atas pertanyaan guru, melalui proses edukatif pairing (berpasangan). Anak didik juga diraih untuk bekerja sama dalam mencari jawaban dan solusi tepat dalam proses edukatif sharing (berbagi) melalui dialogis dalam sebuah kelompok belajar yang dilakukan dalam kelas (Thobroni, 2016).

Bidang studi IPA sains adalah terjemahan kata science yang bermakna alam (nature). Sains sendiri diartikan sebagai ilmu yang menelusuri tentang gejala-gejala alam atau perilaku alam semesta (Usman Samatowa, 2010). Sains juga sebagai bidang pengetahuan yang menela 'ah hakikat kebenaran melalui peragaan uji coba melalui media ilmiah. Sains merupakan metode guna memperoleh hasil penelitian ilmiah sehingga data dan informasi perihal alam semesta secara teruji dan terbukti melalui hipotesis yang telah dikaji dan dapat dipertanggung jawabkan (Uus Toharudin, Sri Hendrawati, 2011).

IPA Sains adalah ilmu pengetahuan yang rasional dan objektif tentang alam semesta dengan segala isinya. IPA Sains adalah cara atau metode untuk mengamati alam dan sifatnya analisis, lengkap, cermat serta menghubungkan antara fenomena dengan kejadian alam dengan perilaku alam yang lainnya. (Hendro Darmodjo, Jenny R.E. Kaligis, 1992:3). Menurut Powler (dalam Winaputra, 1992:122), bidang studi IPA Sains adalah ilmu pengetahuan yang mempelajari perilaku alam semesta secara sistematis yang dilakukan dengan penelitian dan hasil eksperimen.

Untuk mencari pembenaran, maka dalam mata pelajaran IPA, guru ditempatkan sebagai pengarah dan mengutarakan permasalahan yang dikaitkan dengan bidang studi yang tengah diteliti, dan meminta setiap anak didik memanfaatkan peluang waktu sebaik mungkin untuk berpikir dan mencari jawabannya. Guru memberikan penjelasan tentang masalah yang terjadi dilingkungan sekitar, dan disesuaikan dengan batasan kemampuan usia mereka. IPA Sains merupakan bagian dari physical science dan life science, antara lain, bidang ilmu astronomi, geologi, meteorologi, kimia, mineralogi, dan fisika. Sedangkan bidang studi life science, adalah biologi yang mencakup anatomi, zoology dan fisiologi. James Conant (dalam Usman Samatowa, 2011) mengatakan, sains dapat dimaknai sederet catatan konsep logis yang berkorelasi satu dengan yang lainnya yang bertumbuh pada hasil riset dalam penelitian ilmiah.

Berdasarkan observasi awal pada konteks Sains pendidikan sekolah dasar (SD), maka pelajaran IPA sangat penting, selain tematik yang identik dengan faktual lingkungan alam dimana seluruh makhluk hidup melakukan aktivitasnya. Demikian pula, anak didik dilatih berpikir logis dan berusaha dalam mencari jalan keluar terhadap persoalan yang tengah dihadapi tentunya masalah disesuaikan dengan sebatas kemampuan setiap anak didik. Artinya, memecahkan masalah yang telah diidentifikasi. Karenanya, bidang studi IPA Sains SD sangat menekankan kepada pengalaman belajar empiris dan ilmiah.

Hasil observasi awal tanggal 20 Juli 2018 dilakukan di SD Negeri Raya Barat I, Kota Bandung, sebagai lokus fokus penelitian, diperoleh data awal dari sehari-hari anak didik pada bidang studi 
IPA kelas IV pada semester 1, tahun pendidikan 2018/2019, secara umum nilai-nilai mereka belum sampai pada target yang telah ditetapkan sekolah yakni angka 70. Artinya, masih rendahnya nilai hasil belajar sehari-hari merupakan persoalan yang perlu dicarikan solusinya.

Temuan tersebut diperoleh alasan, antara lain; 1) adanya rasa bosan belajar IPA Sains dalam kelas, 2) bidang studi IPA Sains dinilai sulit dipelajari, 3) anak didik merasa bosan belajar pada buku paket (monoton), 4) siswa enggan menanya kepada guru kelas, 5) anak didik belum pernah cara berorganisasi suatu tim kelompok/diskusi belajar dan bersifat individualistis, 6) siswa hanya menerima mata pelajaran dan tidak diajarkan untuk berpikir merdeka belajar. Kendala lainya adalah muncul dari guru, yakni; 1) penyampaian materi ajar dilakukan konvensional yakni model ceramah, buku pegangan dan kurang diperkenalkan dalam lingkungan sekitar, 2) perlu dilakukan pendekatan persuasif dengan anak didik agar terbangun interaksi secara baik, 3) kurang diajarkan cara berorganisasi belajar dalam kelompok belajar. Dalam pembelajaran guru SDN Raya Barat I Kota Bandung, terlihat para guru masih konvensional dan kurang berinovasi.

Untuk memperoleh skor nilai anak didik, maka dilakukan observasi terhadap kegiatan guru dan anak didik dengan menerapkan metode TPS. Tujuan TPS untuk membangun perhatian anak didik dan memotivasi dan menumbuhkan minat belajar anak didik terhadap pelajaran, mengerjakan tugas, kemudahan anak didik memahami setiap mata pelajaran sehingga hasil belajar mereka dapat tercapai. Dengan demikian, identifikasi masalah yakni bagaimana analisis edukasi kooperatif dengan metode TPS tiada lain untuk mengatrol hasil belajar bidang studi IPA anak didik SDN Raya Barat I Kota Bandung?

\section{TINJAUAN PUSTAKA}

(Amri \& Khoiru Ahmadi, 2010), mengatakan, bahwa metode edukasi kooperatif adalah pengajaran terhadap anak didik dengan cara kelompok belajar terbatas dengan tingkat kemampuan yang berbeda, sehingga dalam menyelesaikan tugas-tugasnya dilakukan dengan berkerjasama dalam kelompok. (Jufri, 2013) mengatakan, dalam pembelajaran kooperatif setiap anak didik dimasukkan ke dalam suatu kelompok kecil untuk melatih dalam memecahkan masalah dengan berkerjasama secara kelompok. Kooperatif inilah yang dibangun untuk anak didik sebagai langkah dalam mencapai tujuan daripada kelompoknya. Maknanya adalah setiap anggota kelompoknya harus respek terhadap sesamanya, yakni membangun kebersamaan dalam memecahkan suatu masalah (Rusman, 2012).

Menurut Trianto, TPS model edukatif kooperatif yang dibangun tiada lain untuk mengetahui pola interaksi anak didik. Frank Lyman (dalam Trianto, 2007) menyatakan, TPS merupakan metode efektif untuk menggali potensi anak didik dalam suasana diskusi atau dialogis dalam kelas. Sementara, Julianto, dkk. (2011), mengatakan, pembelajaran kooperatif model TPS setiap anak didik yang dikelompokkan dengan berpasangan, misalnya; 1). Menggalang partisipasi, 2) Membuat tugas-tugas sekolah sederhana, 3) interaktif dalam berkontribusi sesama anggota kelompok, 4) kemudahan dalam berdiskusi dan interaksi antar anak didik, 5) efisien dalam membentuknya.

Melalui TPS hasil belajar lebih efektif. Pada proses penilaian sangat mudah dan memberikan data dan informasi lebih jelas, sehingga setiap guru akan lebih mudah mengetahui 
prestasi yang dicapainya. Dengan demikian, hasil pengajaran terhadap anak didik melalui model TPS mampu membentuk kemampuan anak didik melalui proses belajar yang gembira. Cooperative learning ini adalah cara belajar anak didik dalam suatu kelompok belajar kecil dengan kolaboratif yang terstruktur dan heterogen (Isjoni, 2010).

Konsep kooperatif bagi peserta didik untuk belajar memecahkan persoalan yang sulit melalui diskusi bersama teman-temannya. Hakikatnya, sebagai insan sosial tentu saja aspek pembelajaran kooperatif adalah bagian dari keseharian (Trianto, 2010). Sudjana mengatakan, secara sosiologis keberhasilan hasil studi anak didik turut dipengaruhi oleh dua faktor yakni, faktor dalam diri anak didik dan dari luar atau lingkungan. Clark mengatakan, anak didik di sekolah hampir 70 persen dipengaruhi tingkat kemampuannya, 30 persen lagi bergantung pada pengaruh lingkungan. Selain kemampuan anak didik juga ada dorongan lain seperti, motivasi untuk belajar, minat dan atensi, sikap dan kebiasaan belajar, sosial ekonomi, ketekunan, dan fisisk da psikis (Sudjana, 2011).

Mata pelajaran IPA Sains adalah ilmu yang berupaya menyingkap sesuatu yang terjadi dari fenomena alam sementara. IPA sendiri adalah cabang pengetahuan dari fenomena alam yang terjadi dalam lingkup kehidupan. Sedangkan Usman (2011), menjelaskan, bahwa IPA Sains adalah ilmu tentang alam semesta. Artinya, ilmu pengetahuan yang mengungkap fakta kejadian alam semesta.

\section{METODE PENELITIAN}

Model penelitian tindakan kelas (PTK) yang digunakan dalam penelitian di SDN Raya Barat I, Kota Bandung, dan subjek penelitiannya terfokus pada anak didik kelas IV SD Raya Barat I Kota
Bandung. Sedangkan jumlah anak didik yang menjadi objek sebanyak 20 orang, 8 orang jenis kelamin pria, dan 11 orang jenis kelamin perempuan. Dalam penelitian terdapat empat komponen, yakni ; 1) perencanaan, 2) pelaksanaan, 3) observasi, dan dalam 4), refleksi.

Pada fase I, perencanaan peneliti menggunakan kegiatan pembelajaran, seperti mempersiapkan alat pembelajaran. Alat pembelajaran yakni silabus, RPP, LKS, dan lembar berkas tes. Fase II, pelaksanaan aksi. Peneliti dalam melakukan tindakan aksi tiada lain untuk mengubah pola belajar kearah yang lebih baik lagi. Sedangkan tenaga pendidik (guru) menggunakan pola belajar kooperasi TPS terhadap semua materi ajar IPA guna meningkatkan kualitas hasil belajar anak didik kelas IV SDN Raya Barat I, Kota Bandung.

Fase III melalui analisis. Pada fase ini, dilakukan secara bersama dengan guru kelas dan kawan sejawat dalam melaksanakan observasi (analisa), guna mendapatkan objektivitas terhadap kondisi faktual dalam proses pembelajaran. Fase analisa tiada lain, memberikan RPP serta lembar kerja observasi terhadap pengamat/observer. Sedangkan pengamat melakukan aksi observasi pengajaran sesuai petunjuk dan instrumen serta aksi guru kelas dan anak didiknya yang telah dipersiapkan sebelumnya. Pada fase IV. Aksi yang dilakukan peneliti, dari hasil refleksi yang berkoperasi dengan indikator hasil, tujuan penelitian, yang belum tergapai harus dilakukan pada fase siklus selanjutnya. Fase refleksi dalam mengkaji hasil lapangan. Diskusi dan observasi untuk melihat keberhasilan dan kegagalan, selanjutnya dapat diperbaiki pada fase selanjutnya. Analisis data dan hasil lapangan, dan evaluasi guna menentukan tindakan aksi apakah kegiatan perlu pengulangan atau perbaikan. 
Teknik pengumpulan data dengan observasi dan tes. Teknik dilakukan melalui kegiatan aksi guru kelas dan peserta didik dengan instrumen lebar kerja tes yang dikerjakan selama proses belajar berlangsung. Sedangkan untuk tes dilaksanakan melihat keberhasilan tes anak didik ketika pada pertemuan tiap akhir siklus. Data yang berhasil dihimpun selama PTK melalui model pembelajaran kooperatif tipe TPS, selanjutnya dianalisis dengan menggunakan metode kualitatif dan kuantitatif. Data hasil observasi aksi guru kelas dan peserta didik diolah dengan menggunakan rumus;

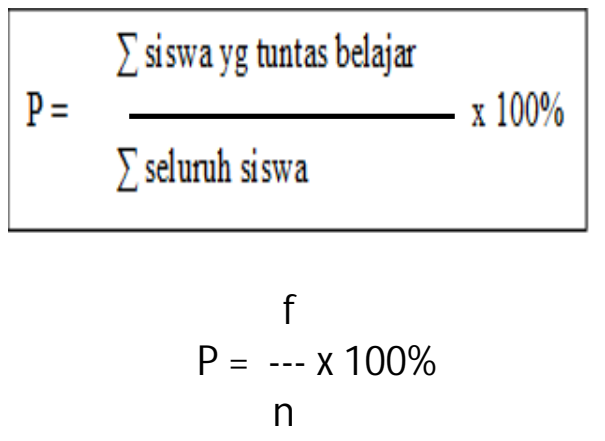

Keterangan:

$\mathrm{P}=$ Persentase frekuensi yang muncul

$\mathrm{f}=$ banyaknya kegiatan anak didik/guru kelas yang muncul

$\mathrm{n}=$ jumlah aktivitas kegiatan keseluruhan

(Indarti, 2008)

Sedangkan hasil observasi jika dibandingkan dengan kriteria penilaian, sebagai berikut;

$$
\begin{array}{ll}
\geq 80 \% & =\text { sangat tinggi } \\
60-79 \% & =\text { tinggi } \\
40-59 \% & =\text { sedang } \\
20-39 \% & =\text { rendah } \\
<20 \% & =\text { sangat rendah }
\end{array}
$$

(Aqib, 2008)
Sementara nilai rata-rata anak didik hasil dari pembelajaran dengan rumus;

$$
M=\frac{\sum \mathrm{fx}}{\mathrm{n}}
$$

Keterangan :

$\mathrm{M}=$ nilai rata-rata

$\sum \mathrm{fx}=$ jumlah nilai dari semua siswa

$\mathrm{N} \quad$ = banyaknya siswa

(Indarti, 2008)

Untuk melihat persentase ketuntasan belajar konvensional dengan menggunakan rumus, sebagai berikut; (Aqib, 2008).

Kriteria penilaian, sebagai berikut;

$\geq 80 \%=$ Sangat tinggi

$60 \%-79 \%=$ Tinggi

$40 \%-59 \%=$ Sedang

$20 \%-39 \%=$ Rendah

$<20 \%=$ Sangat Rendah

(Aqib, 2008)

\section{HASIL DAN PEMBAHASAN}

\section{Siklus I}

Pada tahapan ini adalah perencanaan. Sebelumnya peneliti melakukan kegiatan rencana aksi terlebih dulu dianalisis hasil belajar anak didik kelas VI SDN Raya Barat I, Kota Bandung. Hasil wawancara dengan guru kelas pada mata pelajaran IPA, pada 10 Agustus 2018, diketahui terdapat permasalahan di kelas IV, baik dari guru kalas, anak didik, dan materi ajar. Berdasarkan hasil observasi, maka peneliti mulai melakukan perencanaan tindakan kelas I. Dalam fase ini, guru kelas mulai mengagendakan pertemuan fase satu dan dua, masing-masing dua jam pertemuan. Dilanjutkan dengan instrumen: Silabus, RPP, LKS dan 
lembar tes, dan berkas data catatan atau rekam belajar dari guru kelas terhadap anak didik dan berkas hasil penilaian belajar.

Pada tahapan implementasi. Selanjutnya dalam tahapan ini aktivitas belajar yang telah disusun merujuk pada model TPS. Kegiatan terdiri atas kegiatan awal, kegiatan inti, dan kegiatan penutup:

\section{a) Tatap muka pada pertemuan I}

Belajar didahului ucapan salam dan doa, diteruskan absensi kehadiran. Guru mulai memulai melakukan apersepsi dan dorongan melalui tanya jawab terhadap siswa sesuai dengan materi ajar. Seperti, "Apakah kalian pernah memperhatikan angsa berenang di tengah danau? Apakah kalian pernah memperhatikan burung elang memangsa seekor ular? Apakah kalian pernah memperhatikan sekelompok kerbau di kepalanya tengah dipatoki burung Jalak hitam?” Setelah prolog, guru mulai masuk pada materi ajar dan menjelaskan topik dan tujuan dan pokok pembelajaran, kemudian memberikan pertanyaan dan diminta siswa untuk memikirkan pertanyaan tersebut secara sendiri dan secara satu kelompok yang berpasangan. Jawaban dikumpulkan di meja guru. Kemudian guru kelas membagikan berkas lembar kerja belajar peserta didik (LKS) untuk kemudian didiskusikan secara bersama dengan kelompoknya. Guru kelas kemudian menilainya atas jawaban yang benar dan yang keliru. Setelah itu, baru dievaluasi dengan tanya jawab. Dilanjutkan dengan mengecek setiap peserta didik jauh mana mereka memahami persoalan yang tengah dikerjakan. Pada akhir kegiatan belajar, guru kelas memberikan award terhadap setiap peserta didik dan kelompoknya. Kemudian menyimpulkan bahan atas atau materi setelah dibahas bersama, dan ditutup doa dan pesan moral guru.

\section{b) Tatap muka pada pertemuan II}

Belajar didahului oleh ucapan salam dan doa, selanjutnya absensi kehadiran siswa. Masuk pada materi pelajaran dan apersepsi serta motivasi melalui tanya jawab seputar lingkungan berkait dengan materi, dan sebelumnya rutinitas pembelajaran. Guru menginformasikan simbiosis dengan alat bantu edukatif. Guru memberikan pertanyaan dan diminta memikirkan pertanyaan yang diajukan. Guru mengorganisasikan siswa ke dalam kelompok berpasangan. Guru membagikan lembar LKS bahan diskusikan bersama. Guru memberikan waktu berdiskusi dan dipresentasikan. Guru meluruskan jawaban yang keliru dan di evaluasi. Siswa diminta duduk kembali, setelah itu guru kelas mengecek pemahaman peserta didik terhadap bahan ajar yang telah dipelajarinya dan kemudian lembar kerja evaluasi. Setelah itu, pada bagian akhir guru kelas menyematkan award kepada peserta didik dan kelompok atas tugas-tugasnya. Guru kelas bersama peserta didik menyimpulkan materi hasil analisis, kemudian ditutup doa dan pesan moral.

Tahap Pengamatan. Guru melakukan aktivitas belajar dengan siswa, ditela 'ah oleh pengamat. Guru bersama pengamat kawan sejawat dua orang yaitu Ibu Santi, dan Ibu Sri Dewi kawan peneliti. Dari observasi didapat data-data dari kegiatan guru, peserta didik, dan hasil nilai peserta didik, antara lain; a) Kegiatan guru kelas pada fase I dengan tingkat keberhasilan mencapai 73,75 persen, b) kegiatan peserta didik ketika belajar pada fase II tingkat keberhasilan mencapai 72,55 persen, c) Sedangkan nilai tes peserta didik kelas IV pada fase I adalah 73,1 persen dan ketuntasan hanya mencapai secara klasikal sebesar 66 persen.

Tahap Refleksi. Dalam bagian ini, pada fase I setelah proses belajar 
pertemuan tatap muka bagian ke II selesai, hasil analisis fase I, maka peneliti kembali mendiskusikan bersama guru kelas dan bersama kawan sejawat guna meriview proses belajar yang sudah dilakukan dan bagaimana solusinya ketika terjadi masalah dalam belajar menggunakan model TPS serta dilakukan berbagai perbaikan pada fase-fase berikutnya.

Kekurangan dan kelebihan pada fase I, yakni kekurangan fase I yakni; 1) peserta didik masih yang kurang fokus pada materi ajar ketika guru tengah menerangkan meski beberapa kali di ulang, misalnya guru kelas membagi kelompok belajar dan menerangkan materi LKS. Masih ada siswa yang kurang berkonsentrasi saat guru menjelaskan. 2) Pembagian kelompok, guru kelas kurang menguasai ruang kelas sehingga berdampak pada kurang fokusnya peserta didik, dan ribut/gaduh, 3) Geologis guru kelas kurang memberikan peluang kepad peserta didik untuk mengutarakan pendapatnya berdasarkan pengetahuannya dan proses pembelajaran masih terpusat kepada guru, 4) Hasil belajar dibawah target indikator keberhasilan.

Kelebihan belajar pada fase I, yakni; 1) Dalam proses dialogis kelompok, terlihat guru kelas fokus dalam memberikan materi ajar terhadap kelompok-kelompok pasangan dan diskusi berjalan dengan baik, meski belum seluruhnya disiplin dalam menggali materi, 2) Guru memaksimalkan dalam memanfaatkan fasilitas dalam kelas saat proses belajar mengajar berlangsung.

Kendala yang muncul dalam Fase I dan cara mengatasinya: Dari pengamatan peneliti, menemukan adanya kendala proses ajar, yakni secara umum setiap siswa dalam kelas meminta penjelasan guru untuk menjawab sendiri pertanyaan yang diberikan guru dan kelas menjadi tidak kondusif. Ada sebagian siswa pasif dan tidak partisipasi dalam kegiatan belajar. Kondisi tersebut, dapat diatasi oleh guru dengan menunjuk siswa secara bergantian untuk menjawab pertanyaan dan ditulis di depan kelas, akhirnya siswa mendapat kesempatan berpartisipasi ketika proses pembelajaran. Kondisi lain yang cukup mengganggu yakni adanya anak agresif dalam kelas dan mengganggu temannya sendiri, namun diatasi dengan sikap persuasif guru. Siswa menyadari bahwa guru memberikan perhatian khusus agar tetap disiplin.

Penelitian pada Fase II. Hasil penelitian fase II dalam implementasi model TPS. Hasil penelitian dideskripsikan merujuk kepada fase-fase PTK. Setiap fase dikembangkan yang sebelumnya di progres dalam perencana, pelaksanaan, pengamatan dan refleksi.

Tahap Perencanaan. Guru kelas merencanakan dalam 2 kali pertemuan tatap muka dalam fase II, antara lain, dalam pertemuan satu (durasi waktu 2 jam) dan pertemuan dua (durasi waktu 2 jam). Instrumen belajar yakni, materi dalam Silabus, RPP, LKS, dan lembar tes dan instrumen penelitian, seperti berkas pengamatan kegiatan guru kelas, peserta didik, dan penilaian.

Tahap Pelaksanaan. Guru mulai perencanaan yang disiapkan dengan implementasi dengan TPS pada mata pelajaran IPA kelas IV SDN I Raya Barat Kota Bandung. Fase II terbagi dengan dua pertemuan. Pertemuan pertama, 13 September 2019. Pertemuan kedua, 20 September 2019. Kegiatan tersebut, dibagi dalam 3 bagian, antara lain; kegiatan awal, materi, dan akhir. Pelaksanaan belajar dengan TPS yang telah dilaksanakan diuraikan sebagai berikut. 


\section{1) Pertemuan I}

Kegiatan proses belajar didahului salam dan doa. Kehadiran siswa. Kemudian masuk pada bahan ajar, guru kelas mengapresiasi dan memotivasi dengan materi tanya jawab seputar kondisi lingkungan yang berkait bahan ajar. Misalnya, "Apakah kalian pernah melihat seekor ular tengah memangsa seekor kodok dipinggir kolam? Apa kalian pikirkan ketika melihat siklus alam tersebut?" Dari pertanyaan tersebut, maka terjadi dialogis antara guru dan peserta didik untuk bercerita tentang pengalamannya tentang materi ajar tersebut. Guru kelas menjelaskan tujuan belajar yang ingin dicapai. Setiap peserta didik agar memahami secara keilmuan tentang siklus makanan dan jejaring rantai makanannya. Guru menjelaskan siklus makanan dan proses pembelajaran. Siswa dalam kelompok masing-masing mengerjakan lembar LKS dan didiskusikan bersama. Guru memberikan kesempatan untuk mempresentasikannya. Guru memberikan pembenaran terhadap jawaban yang keliru, dan dievaluasi serta menilai pemahaman siswa sebelum dan sesudah diskusi. Pembelajaran ditutup doa dan pesan moral guru.

\section{2). Pertemuan II}

Belajar di awali dengan kegiatan salam dan doa. Absensi kehadiran. Materi pokok bahasan. Guru melakukan penelaahan dan memberikan dorongan terhadap peserta didik agar memperhatikan penjelasannya tentang makhluk hidup beserta alasannya. Setelah dipandang cukup, maka baru diberikan materi ajar kepada setiap peserta didik dengan pokok bahasan yang harus dipelajari pada peserta didik. Dalam segmen ini guru kelas memberikan informasi tentang siklus hidup dengan alat peraga agar memudahkan serta dapat dipahami peserta didik. Alat peraga tersebut, yaitu tumbuhan dan air. Guru kelas memberikan informasi simbiosis antara makhluk hidup dengan makhluk yang tak hidup. Dilanjutkan dialogis dan tanya jawab. Setiap peserta didik dimintai untuk memberikan pertanyaan secara personal guna melihat pemahaman dalam penyerapan materi ajar. Siswa berkumpul sesuai kelompoknya. Guru membagikan LKS untuk diskusikan dan guru memberikan kesempatan untuk diskusi dan membagikan hasil diskusinya kepada teman sekelasnya untuk dipresentasikan. Guru memberikan pembenaran terhadap jawaban yang keliru, dan evaluasi. Ditutup doa dan pesan moral, dan kembali pada pertemuan berikutnya.

Tahap Pengamatan. Proses pembelajaran, aktivitas guru kelas dan siswa diobservasi yang diamati. Guru kelas dibantu dua orang pengamat yaitu Ibu Sumiati, guru kelas IV dan Sri Devi sejawat peneliti. Observasi diperoleh data kegiatan guru kelas, peserta didik dan hasil belajar, yakni; 1) kegiatan guru kelas pada Fase II memperoleh persentase keberhasilan sebesar 80,50 persen, 2) kegiatan peserta didik dalam belajar pada Fase II diperoleh sebesar 85,55 persen, 3) Nilai rata-rata hasil tes belajar kelas IV pada Fase II sebesar 95,5 dengan ketuntasan sebesar 95 persen.

Tahap Refleksi. Secara keseluruhan implementasi penelitian dengan model TPS pada materi ajar IPA pada siswa kelas IV SD, cukup signifikan dan siswa dapat mengikuti kegiatan pada Fase II dengan baik. Dibuktikan dengan hasil belajar mencapai keberhasilan $\geq$ 95,5 persen. Lihat diagram I, hasil belajar peserta didik. 


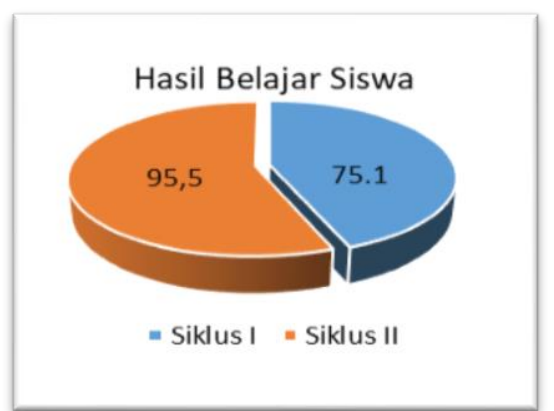

Diagram 1. Hasil Belajar Kognitif Siswa

Nilai rata-rata hasil belajar cukup signifikan. Fase I, rata-rata mendapat nilai 70,5 dengan ketuntasan klasikal sebesar 73 persen. Hasil belajar ini belum mencapai Kriteria Ketuntasan Minimal (KKM) yakni $\geq 80$ belum maksimal karena ketentuan indikator keberhasilan $\geq$ 90. Penelitian diteruskan kepada Fase II dengan harapan hasil lebih baik.

Refleksi Fase I, diteruskan pada Fase II dan II. Fade II terdapat peningkatan rata-rata kelas menjadi 85,5. Persentase ketuntasan mencapai 90 persen. Nilai rata-rata kelas mencapai indikator keberhasilan $\geq 85$ persen dan presentasi ketuntasan klasikal melebihi indikator keberhasilan $\geq 80$ persen. Lihat diagram 2.

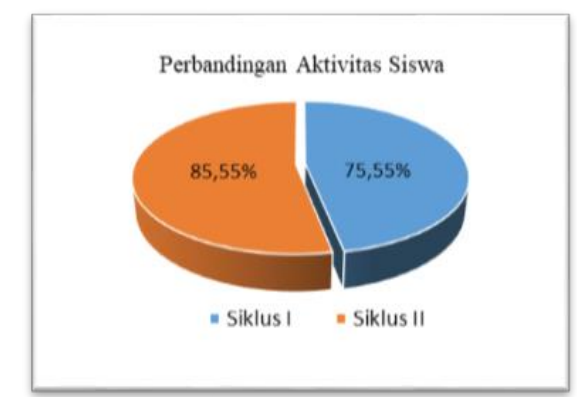

\section{Diagram 2. Persentase ketuntasan klasikal}

Dari hasil analisis yang berdasar pada nilai rata-rata kelas, tampak implementasi belajar dengan model TPS mengalami peningkatan. Ini berarti ada kenaikan belajar setelah adanya interaksi dalam kelompok belajar. Setiap peserta didik lebih dapat mengajari temantemannya yang kurang bisa.

Peningkatan belajar juga naik pada afektif dan psikomotor. Dampak tersebut, memberikan afektif terhadap peserta didik yang mengalami kenaikan sebesar 75,45 persen pada fase I menjadi 95,55 persen pada fase II. Kondisi tersebut, disebabkan perilaku para peserta didik dalam belajar semakin baik. Mereka dapat bekerja sama secara kelompok, dan mampu mengutarakan pendapat serta belajar menghargai pendapat temannya sendiri. Meningkatnya ketuntasan hasil belajar peserta didik dapat dilihat pada diagram 3.

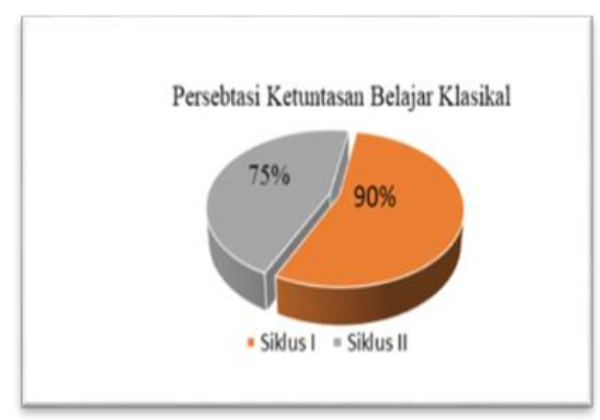

\section{Diagram 3. Ketuntasan Hasil Belajar Afektif}

Psikomotor peserta didik pada Fase I dari 75 persen naik menjadi 83,33 pada Fase II. Ini menunjukkan setiap anak mampu menempatkan diri sesuai dengan yang diminta, seperti terlihat ketika mereka mempresentasikan sesuai dengan kemampuannya. Ketuntasan klasikal hasil belajar psikomotor siswa. Lihat diagram 4. 


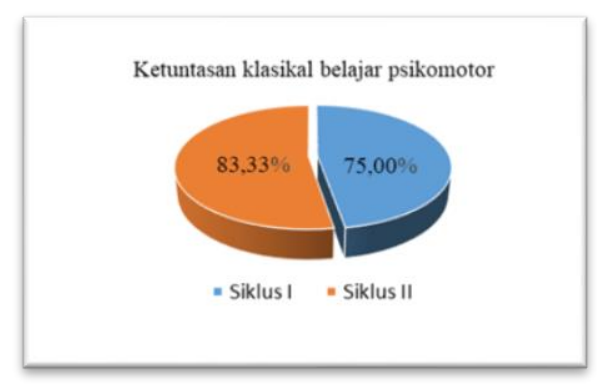

\section{Diagram 4. Hasil Belajar Psikomotor Anak didik}

Ketuntasan belajar anak didik tidak lepas dari dorongan dan proses pendidikan yang dilakukan atas kerja sama antara guru dan anak didik. Ketuntasan tersebut, mencapai keberhasilan, yaitu $\geq 90$ persen dari kegiatan belajar anak. Pada Fase II, juga terjadi kenaikan sebesar 10 persen, yaitu dari 75,55 persen pada Fase I menjadi 85,55 persen pada Fase II. Aspek menonjol yakni respons adanya simbiosis antara guru dan hasil kerja kelompok yang mencapai 20 persen. Siswa semakin termotivasi dalam mengikuti pembelajaran mandiri. Lihat diagram 5.

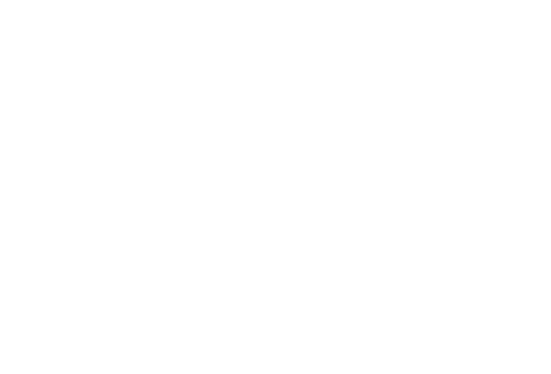

Diagram 5. Persentase Aktivitas Siswa

Peningkatan setelah adanya perbaikan mekanisme pembelajaran dan pengelolaan belajar dalam kelas. Model TPS yang digunakan pada kelas IV dengan sangat baik. TPS telah sesuai dan dapat meningkatkan kualitas pembelajaran siswa kelas IV SD. Tentunya saja tidak lepas dari pembinaan guru dalam kelas. Lihat diagram 6.

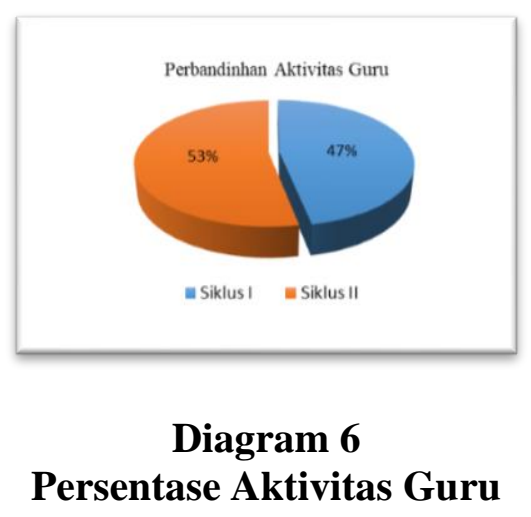

Aktivitas guru semula pada Fase I sebesar 75,55 persen, naik menjadi 85,65 pada Fase II. Persentase ini telah mencapai target. Aktivitas guru mengalami peningkatan sebesar 10,10 persen. Aktivitas guru, terlihat menonjol ketika melihat penguasaan anak didik dalam penyerapan materi ajar. Materi ajar dari guru dapat diserap anak didik. Disimpulkan bahwa penerapan TPS diterima dan mampu meningkatkan belajar anak kelas IV SD. TPS merupakan model yang efektif untuk diterapkan pada kelas IV SD khususnya pada materi ajar Ilmu Pengetahuan Alam.

\section{KESIMPULAN}

Hasil penelitian dan pembahasan disimpulkan bahwa TPS pada mata ajar IPA siswa kelas IV SD terbukti dapat meningkatkan hasil belajar secara signifikan. Peneliti memberikan saran berupa;

a) Penerapan mata pelajaran IPA, dengan menggunakan model TPS, guru tetap persuasif edukatif agar memotivasi belajar dengan media belajar yang ada di sekolah serta lingkungan setempat.

b) Dalam menerapkan model TPS agar tidak terpusat pada guru atau tenaga pendidikan. 


\section{UCAPAN TERIMA KASIH}

Kepada semua civitas akademika FKIP UNPAS, dicapkan terima kasih yang telah membantu dan mendukung kelancaran dalam penelitian ini, wabil khusus ke kawan-kawan di Dinas Pendidikan dan Kebudayaan Kota Bandung dan SDN Raya Barat. Ucapkan terima kasih juga tidak lupa saya ucapkan kepada Pemkot Bandung, yang telah membantu kelancaran penelitian, dan kawan-kawan yang telah berkontribusi yang tidak saya sebut satu per satu atas gagasan dan pemikiran dalam penelitian ini.

\section{DAFTAR PUSTAKA}

Amri, Sofan dan IIF Khoiru Ahmadi. (2010). Proses Pembelajaran Kreatif dan Inovatif Dalam Kelas. Jakarta: Prestasi Pustakaraya.

Aunurrahman. (2011). Belajar Dan

Pembelajaran. Bandung: $\mathrm{CV}$. Alfabeta.

Aqib, Zainal. (2008). Penelitian Tindakan

Kelas untuk Guru SD, SLB, TK.

Bandung: CV.Yrama Widya.

Goodhue \& Thompson (1995). Task-

Technology Fit and Individual

Performance, McGraw-Hill, New York

Hendro Darmodjo, dan Jenny R.E. Kaligis. (1992). Pendidikan IPA II. Jakarta: Depdikbud, hlm 3.

Indarti, Titik. 2008. Penelitian Tindakan

Kelas dan Penelitian Ilmiah.

Surabaya, FBS Unesa, hlm 76.
Isjoni, 2009, Pembelajaran Kooperatif:

Meningkatkan Kecerdasan

Komunikasi Antar Peserta Didik, Yogyakarta: Pustaka Pelajar, hlm.15.

Jihad, Asep dan Abdul Haris. 2013. Evaluasi Pembelajaran. Yogyakarta: Multi Pressindo.

Julianto. 2011. Model pembelajaran IPA. Surabaya: Unesa University Press.

—, dkk. 2011. Teori Dan Implementasi ModelModel Pembelajaran Inovatif. Surabaya: Unesa University Press.

Johnson, D. W., Johnson, R. T. \& olubec, E. J. (2004). Colaborative Learning. Penerjemah: Narulita Yusron. Bandung: Nusa Media.

Jufri, Wahab. 2013. Belajar dan Pembelajaran SAINS. Bandung: Pustaka Reka Cipta.

Kurniasih dan Sani. (2015). Model

Pembelajaran.Yogyakarta: Kata Pena, hal 58.

Mulyasa. 2013. Pengembangan dan Implementasi Kurikulum 2013. Bandung: PT Remaja Rosdakarya. Nana Sudjana, (2011). Dasar-Dasar Proses Belajar Mengajar. Bandung: Sinar Baru Algensindo. 
Robert. E Slavin. (2010). Cooperative Learning Teori, Riset dan Praktik. Bandung:Nusa Media.

Rusman. 2012. Model-Model Pembelajaran Mengembangkan Profesionalisme Guru. Jakarta: PT Raja Grafindo PersadaSudjana, Nana. 2011. Dasar-Dasar Proses Belajar Mengajar. Bandung: Sinar Baru Algensindo.

Samatowa, Usman. 2010. Pembelajaran IPA Di Sekolah Dasar. Jakarta: PT Indeks.

Thobroni. (2016). Belajar dan Pembelajaran Teori dan Praktek. Jakarta : AR-RUZZ MEDIA

Trianto. 2007. Model-Model Pembelajaran Inovatif Berorientasi Konstruktivistik. Surabaya:Prestasi Pusaka.

Pembelajaran Inovatif-Progresif, Jakarta: Kencana, hlm.56.

Usman Samatowa. (2010). Pembelajaran IPA di Sekolah Dasar. Jakarta: PT Indeks.

Uus Toharudin, Sri Hendrawati, dan Andrian Rustaman. (2011). Membangun Literasi Sains Siswa. Bandung: Humaniora, hlm 25-27.
Winaputra, U. (1992). Strategi Belajar Mengajar IPA. Jakarta: Universitas Terbuka, hlm 122.

Zainal Aqib. (2008). Penelitian Tindakan Kelas Untuk Guru. Bandung: Yrama Widya., hal 40-41 